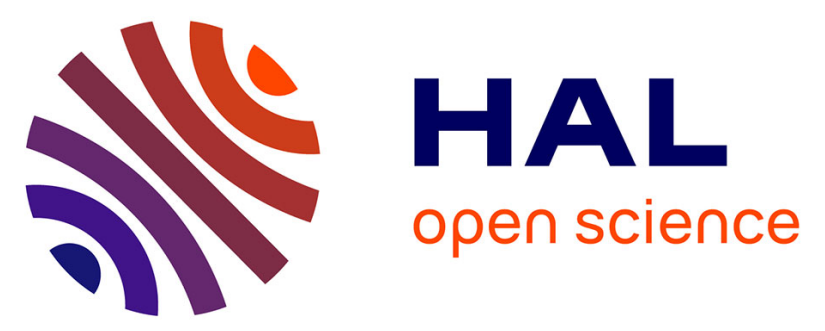

\title{
Mortality and Predictors of Death Poststroke: Data from a Multicenter Prospective Cohort of Lebanese Stroke Patients
}

Rachel Abdo, Halim Abboud, Pascale Salameh, Taghrid El Hajj, Hassan Hosseini

\section{To cite this version:}

Rachel Abdo, Halim Abboud, Pascale Salameh, Taghrid El Hajj, Hassan Hosseini. Mortality and Predictors of Death Poststroke: Data from a Multicenter Prospective Cohort of Lebanese Stroke Patients. Journal of Stroke and Cerebrovascular Diseases, 2019, 28, pp.859 - 868. 10.1016/j.jstrokecerebrovasdis.2018.11.033 . hal-03486249

\section{HAL Id: hal-03486249 \\ https://hal.science/hal-03486249}

Submitted on 20 Dec 2021

HAL is a multi-disciplinary open access archive for the deposit and dissemination of scientific research documents, whether they are published or not. The documents may come from teaching and research institutions in France or abroad, or from public or private research centers.
L'archive ouverte pluridisciplinaire HAL, est destinée au dépôt et à la diffusion de documents scientifiques de niveau recherche, publiés ou non, émanant des établissements d'enseignement et de recherche français ou étrangers, des laboratoires publics ou privés.

\section{(ㄷ)(1) $\$$}

Distributed under a Creative Commons Attribution - NonCommercial| 4.0 International 


\title{
Mortality and predictors of death post stroke: Data from a multicenter prospective cohort of Lebanese stroke patients
}

\author{
Rachel Abdo ${ }^{1-3}(\mathrm{PhD})$, Halim Abboud ${ }^{4}(\mathrm{MD})$, Pascale Salameh ${ }^{3,5}(\mathrm{PhD})$, Taghrid \\ El Hajj ${ }^{5-6}$ (MD) and Hassan Hosseini ${ }^{7}$ (MD)
}

${ }^{1}$ Laboratory of Clinical and Epidemiology Research, Faculties of Pharmacy and of Public Health, Lebanese University, Beirut, Lebanon.

${ }^{2}$ Doctoral School of Life and Health Sciences, Paris-Est University, Creteil, France. ${ }^{3}$ INSPECTLB (Institut National de Santé Publique, d'Epidémiologie Clinique et Toxicologie - Liban), Faculty of Public Health, Fanar, Lebanon.

${ }^{4}$ Department of Neurology, Faculty of Medicine, Saint Joseph University, Beirut, Lebanon.

${ }^{5}$ Faculty of Medicine, Lebanese University, Beirut, Lebanon.

${ }^{6}$ Department of Neurology, Rafic Hariri University Hospital, Beirut, Lebanon.

${ }^{7}$ Department of Neurology, Henri Mondor Hospital AP-HP, Creteil, France.

Corresponding author:

Rachel Abdo, Laboratory of Clinical and Epidemiology Research, Faculties of Pharmacy and of Public Health, Lebanese University, Beirut Lebanon; Doctoral School of Life and Health Sciences, Paris-Est University, Creteil, France.

Email: rachelabdo@hotmail.com

Telephone number: 009613660581

ORCID: 0000-0001-8131-1676

Short title: Mortality and predictors of death post stroke in Lebanon

Keywords: Stroke; mortality; predictors; short-term; long-term; Lebanon 


\section{Abstract}

Background: Despite efforts to reduce stroke mortality rates, the disease remains a leading cause of death in Lebanon highlighting the importance of understanding risk factors and subsequent mortality. We examined mortality rates during the first year after acute stroke and the major short-term (1-month) and long-term (1-year) mortality predictors.

Methods: Data were collected prospectively on hospitalized stroke patients from eight hospitals in Beirut during a 1-year period. Pat ients were followed up for 1-year or unt il death. Mortality rates were assessed at 1-month and at 1-year post stroke and predictors of death were evaluated using Cox proportional hazard model.

Results: A total of 191 stroke patients were included. Survival data were completed for over $97 \%$ of patients. Cumulative mortality rates were $14.1 \%$ at 1 -month and $22.0 \%$ at 1 -year. Predictors of short-term and long-term mortality in univariate analysis were low socioeconomic status, intensive care unit admission, decreased level of consciousness, stroke severity and presence of complications. Marital status also predicted short-term mortality, while age $>64$ years, atrial fibrillation, coronary heart disease, hypertension, Bamford and TOAST classifications and surgery need were also long-term mortality predictors. In multivariate analysis, stroke severity and presence of complications were predictors of death at 1-month and at 1-year. Low socioeconomic status, dependency in daily living activities, and the presence of co-morbidities were additional predictors of 1-year mortality.

Conclusion: Approximately one over five of patients did not survive 1-year after stroke. There is a need for public awareness campaigns to improve stroke knowledge, warning and prevention which may reduce this high stroke mortality rate in Lebanon. 


\section{Introduction}

Stroke is the third leading cause of death ${ }^{(1)}$ with an annual 6 million fatal events worldwide. ${ }^{(2)}$ Most of these stroke deaths are found in the developing countries and account for as much as $87 \%$ of all the stroke deaths. ${ }^{(3)}$

According to the World Health Organization, 15 million people suffer stroke worldwide each year. Of these, 5 million die, and another 5 million are left permanently disabled. ${ }^{(4)}$

The prognosis after acute stroke varies greatly in individual patients, depending on stroke severity, stroke characteristics (location and size) and on the patient's premorbid condition, age and post-stroke complications. ${ }^{(5)}$ In fact, post-stroke complication is a leading cause of death accounting for $23-50 \%$ of total deaths in patients with ischemic stroke. ${ }^{(6)}$

Stroke mortality is an important outcome measure in stroke epidemiology studies and clinical trials, and data on stroke mortality are critical for monitoring disease trends and planning public health interventions. Furthermore, identifying predictors of mortality after acute stroke is of paramount importance for clinicians, so that specific therapies and management strategies can be applied to patients at high risk of dying with a consequent reduction in stroke mortality and disability.

There is paucity in literature in regards to the data about stroke mortality due to a lack of studies in Lebanon. ${ }^{(7)}$ The aim of this study was to investigate the stroke mortality rates and examine its major potential predictors of short-term and long-term mortality in a multicenter hospital-based cohort of Lebanese stroke patients.

\section{Methods}

The ethical committees of all the participating hospitals approved the study. Participants (or their responsible caregivers where not possible) provided written informed consent. 


\section{Study design}

Stroke patients aged $\geq 18$ years, admitted during 1-year period from August 2015 in 8 different hospitals in Beirut (6 private university hospitals, 1 private community hospital, and 1 public university hospital) were included prospectively in this study and followed up for one year or until death. Stroke was defined according to the International Classification of Diseases (10th revision) including subarachnoid hemorrhage, intracerebral hemorrhage and cerebral infarction; Transient Ischemic Attack (TIA) was defined as a brief episode of neurologic dysfunction resulting from focal temporary cerebral ischemia and not associated with cerebral infarction. ${ }^{(8)}$ TIA patients, patients admitted after seven days of symptoms onset or those who refused to give their consent were excluded. Patients were also excluded if they were suffering from severe pathologies with unfavorable 1-year prognosis (cancer, fatal renal, hepatic or respiratory insufficiency), or having a moderate to severe cognitive decline before their stroke.

\section{Study tools}

A structured data form including demographics, characteristics, and diagnostic tests performed was completed for all patients. Stroke severity on admission was assessed with the National Institute of Health Stroke Scale (NIHSS) ${ }^{(9)}$ and classified as no stroke symptoms (score of 0), mild (score of 1 to 4), moderate (score of 5 to 14), moderate/severe (score of 15-20) and severe (score of $\geq 21$ ). Clinical classification of the ischemic stroke was assessed using the Oxfordshire

Community Stroke Project (Bamford classification) ${ }^{(10)}$, and clinical outcome was assessed using modified Rankin Scale (mRS). ${ }^{(1)}$ Patients were classified into 3 groups according to mRS (Independent [0 to 2 points], dependent [3 to 5 points] and dead [6 points]) and to four groups according to BI (Independent [96-100], mild dependence [75-95], moderate dependence [46-74] 
and severe dependence [0-45]). ${ }^{(12)}$ Stroke etiology was classified using to the Trial of Org 10172 in Acute Stroke Treatment (TOAST) criteria. $^{(13)}$

Mortality rates were prospectively assessed by a researcher pharmacist (R.A.) at 1-month and at 12-months post-stroke by visiting each patient at the place he/she was residing at that time (home/institution/rehabilitation center/hospital).

\section{Risk factors assessment}

The presence of a previous stroke was determined on the basis of history and review of medical records. The existence of concurrent medical illness was determined by history, physical examination, laboratory data, and review of medical records. Risk factors such as hypertension, diabetes mellitus (type 1 or 2), dyslipidemia and atrial fibrillation were defined by the use of medications for these conditions at the time of study enrolment or at hospital discharge. The data for baseline information on smoking status were also collected.

Education level, employment status and monthly personal income were used as indicators of Socio-Economic Status (SES).

\section{Statistical analysis}

Cumulative mortality rates at 1-month and 1-year follow-ups were calculated for all stroke patients. Differences in baseline variables between survivors, non-survivors and lost to follow up at 1-year after the stroke were assessed withthe $\chi^{2}$ test (or exact Fisher) for proportions and ANOVA (analysis of variance) test (or Kruskal Wallis) for between-group comparison. Determinants of death were evaluated using the Cox proportional hazard model at 1-month, 1year and overall death. Univariate associations between mortality and each of the individual variables that were identified as possible predictors of mortality were assessed using KaplanMeier survival analysis and significance determined using the log rank test. The identified 
predictors with a univariate $\mathrm{p}<0.2$ were subjected to multivariate Cox regression analyses using forward stepwise selection. Hazard ratios for mortality were determined by univariate and multivariate Cox proportional hazards regression analyses, with data presented as hazard ratio with $95 \%$ CIs. Log minus log plots were evaluated to test the validity of the proportionality of hazards assumption over time; all variables met this assumption. The Kaplan-Meier overall mortality curves was presented. At 1-year follow-up, data analysis was conducted only for 1month survivors. The P-value of $\leq 0.05$ was considered statistically significant. Analyses were performed with the SPSS 21.0 software.

\section{Results}

One hundred and ninety one patients were included in this study (approximately 5\% of patients did not give their written consent and were therefore excluded from the study); the mean age was $69 \pm 13$ years and $57 \%$ were men (Table 1). Survival data during the study period were complete for over $97 \%$ of patients. No significant difference was observed between lost to follow up and followed up patients concerning socio-demographic and clinical characteristics (Tables 1 and 2). Cumulative rates of mortality were $14.1 \%$ at 1 -month and $22.0 \%$ at 1 -year follow-up. The risk of death was highest in the first month. For 1-month survivors, the mortality rate during 3, 6 and 12 months after the stroke was approximately $4.9 \%, 1.3 \%$ and 3.2\% respectively. Fifteen of the 164 survivors at 1-month $(9.1 \%)$ did not survive at 1-year after the stroke. Overall mortality curve is shown in figure 1.

Table 1 presents the socio-demographic characteristics of the study population according to survival status at 1-month and 1-year. Survivors at 1-month (85.9\%) and at 1-year (75.4\%) were significantly younger than the deceased (mean age: $68 \pm 12$ years for 1 -month survivors vs. $77 \pm 12$ for 1 -month deceased, $\mathrm{p}=0.001 ; 67 \pm 12$ years for 1 -year survivors vs. $76 \pm 12$ for 1 -year deceased, 
$\mathrm{p}<0.001)$. Gender, education and living status were not statistically significant factors for mortality. However, the proportion of 1-month deceased patients was significantly lower among married patients, compared with single/divorced/widowed patients $(\mathrm{p}=0.036)$. Higher 1-month and 1-year death occurred in housewife and unemployed patients compared to employed and retired patients ( $\mathrm{p}=0.050$ and 0.004 respectively) and in patients with low monthly personal income compared to high monthly personal income ( $\mathrm{p}=0.040$ and 0.017 respectively).

Table 2 presents the clinical characteristics of the patients by survival status at 1-month and 1year. No statistically significant difference was noted between survivors and non-survivors regarding stroke types. Hypertension was the only risk factor statistically significant between survivors and non-survivors for mortality at 1 -year $(\mathrm{p}=0.009)$ Hypertensive patients had higher stroke mortality rates $(27.1 \%$ vs. $8.7 \%)$. No statistically significant difference was observed for other common risk factors such as diabetes mellitus, dyslipidemia, atrial fibrillation, coronary heart disease, recurrent stroke and smoking. Stroke severity and infectious complications were significantly associated to mortality at one and 12 months ( $<<0.001)$. The mRS was significantly lower and BI was significantly higher among alive patients compared to deceased at 1-month and at 1-year. Cardio-embolic and atherosclerosis stroke had the highest mortality rates between ischemic strokes and the highest mortality rates were found for patients with total anterior circulation stroke.

Variables identified in the univariate survival analysis as independent predictors of death at 1month, 1-year and overall mortality are presented in table 3. Decreased level of consciousness, high NIHSS score and the presence of infectious complications were predictors of 1-month, 1year and overall mortality. Marital status, low monthly personal income and intensive care unit 
(ICU) admission were additional 1-month mortality predictors. High mRS, low BI score, surgery needed and the presence of co-morbid conditions such as recurrent stroke, atrial fibrillation and coronary heart disease were additional 1-year mortality predictors. Additional predictors of overall mortality were age >64 years, low monthly personal income, employment status, ICU admission, surgery needed (coiling, craniotomy, shunt, carotid endarterectomy, gastrostomy and tracheostomy), TOAST and Bamford classifications (for ischemic strokes) and the presence of hypertension as a co-morbid condition.

Variables identified in the multivariate survival analysis as independent predictors of death at 1month, 1-year and overall mortality are presented in table 4. Stroke severity and infectious complication occurrence were predictors of death at 1 -month $(\mathrm{HR}=1.1, \mathrm{p}=0.004 ; \mathrm{HR}=4.2$, $\mathrm{p}=0.013$ respectively) and overall death $(\mathrm{HR}=1.1, \mathrm{p}<0.001 ; \mathrm{HR}=3.0, \mathrm{p}=0.007$ respectively); however, disability in daily living activities (low BI score $\mathrm{HR}=0.14, \mathrm{p}=0.003$ ), atrial fibrillation $(\mathrm{HR}=4.6, \mathrm{p}=0.035)$ and recurrent stroke $(\mathrm{HR}=4.7, \mathrm{p}=0.024)$ were additional predictors of longterm mortality for patients alive 1-month post stroke.

Considering employed status as reference, unemployed patients had a significantly higher 1-year and overall mortality rate ( $\mathrm{p}=0.003$ and 0.007 respectively).

In the multivariate analysis for ischemic stroke cases only, TOAST and Bamford were not statistically significant and were removed from the model (Supplementary file, Table 5).

\section{Discussion}

This prospective study was designed to find out both short- and long- term stroke mortality and their major determinants in hospitalized patients followed up for a year after an acute stroke.

Cumulative mortality rates for stroke patients increased from approximately one over seven at 1month to one over five 1-year after the event. Almost one over eleven of survivors at 1-month 
did not survive at 1-year. In addition we found that the first two weeks after stroke onset comprise a critical period for stroke patients since $12 \%$ and $31 \%$ died within the first and second week respectively. The non-survivor's percentage increased after the first two weeks getting to $64 \%$ by the end of thirty days. Our findings are not surprising. A Canadian study reported close 30-day and 1-year mortality rates after stroke of $13 \%$ and $24 \%$ respectively $^{(14)}$ which are consistent with our findings. However prior studies have reported lower 1-month and 1-year mortality rates ${ }^{(15-16)}$ while others reported a slightly higher rates than ours. ${ }^{(17-18)}$

Several factors are known to influence short- and long -term mortality. As expected, we found that initial stroke severity and infectious complications were independent determinants of shortand long-term mortality. Our findings support previous reports where stroke severity ${ }^{(14,16,19-21)}$ and infectious complications ${ }^{(7,14,21-22)}$ were independent strong predictor of short- and long-term mortality. Therefore, reducing stroke severity and the risk of infection will therefore be paramount in curtailing the mortality rate. Patients with high initial stroke severity or higher risk for infection may benefit from early treatment, preventative interventions and sooner outpatient follow-up.

Recurrent stroke, hypertension and atrial fibrillation are positively associated with post-stroke death and this is consistent with previous studies. ${ }^{(23-25)}$ Therefore, improved control of these modifiable risk factors can potentially prevent part of stroke mortality. Efforts should be also done on primary prevention measures in order the reduce stroke incidence and therefore stroke mortality.

Patients having a higher BI (being independent in DLA) were significantly more likely to survive than those with a lower score. In fact, as proven in other studies ${ }^{(26)}, \mathrm{BI}$ is a useful predictor for 1year mortality and being dependent in DLA increase the long-term mortality rate. 
Unemployed patients had lower survival rate compared to employed patients . Many studies show that persons in lower socioeconomic positions, such as low-income groups, have higher risk of dying from stroke. ${ }^{(27-28)}$ Understanding the causal associations between SES and stroke will allow interventions to be appropriately targeted and assessed.

Even though age, decreased level of consciousness, ICU admission and were removed when entered in the multivariate Cox regression, they were positively associated with death at both 1month and 1-year periods and with overall death in the univariate analysis. In fact, they emerged as predictors of stroke mortality in many previous studies. ${ }^{(15-20,24)}$

\section{Strengths and Limitations of the Study}

This study has some limitations. The first limitation is the small number of patients. In fact, Lebanon is a small country of approximately 4.3 million people in $2012 .^{(29)}$ Therefore, it was expected to have this number despite our effort to include all stroke patients in these 8 different hospitals in Beirut region. In addition, even though we have tried to screen all stroke patients in this study we might have missed some of them for different reasons (such as transferred patients to another hospital, etc...), which may also contribute to this small number of patient. However, we have no reason to believe that the associations we found would be different in larger more representative studies, except for some associations that may not show statistical significance because of the sample size of our study. Second, we did not include patients who were demented, died before hospitalization or died within less than 24 hour from admission, which may give rise to a selection bias, and therefore we think that mortality rate is underestimated in our study. Third, even though patients came from all governorates, hospitals were limited to Beirut region. Future studies taking into account all the weak points and including a larger sample size from all Lebanon regions must be done to confirm our findings. 


\section{Conclusion}

The important predictors of mortality found in our study were stroke severity and infectious complications. Low SES and the presence of comorbid conditions such as hypertension, atrial fibrillation and recurrent stroke were also predictors of long-term mortality.

There should be public awareness campaigns to educate the public on stroke symptoms and risk factors and their modifiable nature. Primary and secondary prevention measures should be of utmost importance. This will reduce both the prevalence of stroke and the severity and therefore the mortality rate. 


\section{Funding}

None

\section{Acknowledgements}

We would like to acknowledge the participating hospitals, particularly administrators, physicians and staff.

\section{Conflicts of interest}

All authors declare that they have no conflict of interest. 


\section{Reference}

1- Feigin VL, Lawes CM, Bennett DA, et al. Worldwide stroke incidence and early case fatality reported in 56 population-based studies: a systematic review. Lancet Neurol. 2009 Apr; $8(4): 355-69$.

2- World Health Organization (WHO). Cardiovascular Diseases. Geneva, Switzerland: WHO; September 2009. WHO Fact Sheet 37.

3- Sagui E. Med Trop (Mars). 2007 Dec; 67(6):596-600.

4- MacKay J, Mensah GA. World Health Organization. Global Burden of Stroke. The Atlas of Heart Disease and Stroke. Available at: <http://www.who.int/cardiovascular_diseases/en/cvd_atlas_15_burden_stroke.pdf>. ） (Last accessed on 26 August 2018)

5- Adams HP Jr, Davis PH, Leira EC, et al. Baseline NIH Stroke Scale score strongly predicts outcome after stroke: A report of the Trial of Org 10172 in Acute Stroke Treatment (TOAST). Neurology. 1999 Jul; 53(1):126-31.

6- Balami JS, Chen RL, Grunwald IQ, et al. Neurological complications of acute ischaemic stroke. Lancet Neurol. 2011 Apr; 10(4):357-71.

7- Riachy M, Sfeir F, Sleilaty G, et al. Prediction of the survival and functional ability of severe stroke patients after ICU therapeutic intervention. BMC Neurology. 2008; 8:24.

8- Easton JD, Saver JL, Albers GW, et al. Definition and evaluation of transient ischemic attack: a scientific statement for healthcare professionals from the American Heart Association/American Stroke Association Stroke Council; Council on Cardiovascular Surgery and Anesthesia; Council on Cardiovascular Radiology and Intervention; Council on Cardiovascular Nursing; and the Interdisciplinary Council on Peripheral Vascular Disease. The 
American Academy of Neurology affirms the value of this statement as an educational tool for neurologists. Stroke 2009; 40:2276.

9- The NINDS t-PA Stroke Study Group. Generalized efficacy of t-PA for acute stroke: subgroup analysis of the NINDS t-PA Stroke Trial. Stroke.1998; 28:2119-25.

10- Bamford J, Sandercock P, Dennis M, et al. Classification and natural history of clinically identifiable subtypes of cerebral infarction. Lancet 1991; 337:1521-6.

11- Sulter G, Steen C, De Keyser J. Use of the Barthel index and modified Rankin scale in acute stroke trials. Stroke. 1999 Aug; 30(8):1538-41.

12- Fattore G, Torbica A, Susi A, et al. The social and economic burden of stroke survivors in Italy: a prospective, incidence-based, multi-centre cost of illness study. BMC Neurol. 2012; 12(1):137.

13- Adams HP Jr, Bendixen BH, Kappelle LJ, et al. Classification of subtype of acute ischemic stroke. Definitions for use in a multicenter clinical trial. TOAST. Trial of Org 10172 in Acute Stroke Treatment. Stroke. 1993; 24(1):35-41.

14- Saposnik G, Hill MD, O’Donnell M, et al. Variables associated with 7-day, 30-day, and 1year fatality after ischemic stroke. Stroke 2008; 39:2318-24.

15- Hartmann A, Rundek T, Mast H, et al. Mortality and causes of death after first ischemic stroke: the Northern Manhattan Stroke Study. Neurology. 2001 Dec 11; 57(11):2000-5.

16- Koton S, Tanne D, Green MS, et al. Mortality and predictors of death 1 month and 3 years after first-ever ischemic stroke: data from the first national acute stroke Israeli survey (NASIS 2004). Neuroepidemiology. 2010; 34(2):90-6.

17- Sawalha A.F. Characterization of Hospitalized Ischemic Stroke Patients in Palestine, Libyan Journal of Medicine. 2008; 4(1):37-40. 
18- Al-Asadi JN, Habib HA. Risk factors and 30-day case fatality of first-ever stroke in Basrah, Iraq. Nigerian Medical Journal : Journal of the Nigeria Medical Association. 2014; 55(3):209213.

19- Rønning OM. Very long-term mortality after ischemic stroke: predictors of cardiovascular death. Acta Neurol Scand 2013; 127(Suppl. 196):69-72.

20- Alonso A, Ebert AD, Kern R, et al. Outcome Predictors of Acute Stroke Patients in Need of Intensive Care Treatment. Cerebrovasc Dis. 2015; 40(1-2):10-7.

21- Ekeh B, Ogunniyi A, Isamade E, et al. Stroke mortality and its predictors in a Nigerian teaching hospital. African Health Sciences. 2015; 15(1):74-81.

22- Das S, Chandra Ghosh K, Malhotra M, et al. Short term mortality predictors in acute stroke. Annals of Neurosciences. 2012; 19(2):61-7.

23- Kaarisalo MM, Immonen-Räihä P, Marttila RJ, et al. Atrial fibrillation and stroke. Mortality and causes of death after the first acute ischemic stroke. Stroke. $1997 \mathrm{Feb} ; 28(2): 311-5$.

24- Sun, Y, Lee $\mathrm{SH}$, Heng $\mathrm{BH}$, et al. "5-year survival and rehospitalization due to stroke recurrence among patients with hemorrhagic or ischemic strokes in Singapore." BMC Neurology $2013 ; 13(1): 133$.

25- Carter AM, Catto AJ, Mansfield MW, et al. Predictive variables for mortality after acute ischemic stroke. Stroke. 2007 Jun; 38(6):1873-80.

26- Higuchi S, Kabeya Y, Matsushita K, et al. Barthel Index as a Predictor of 1-Year Mortality in Very Elderly Patients Who Underwent Percutaneous Coronary Intervention for Acute Coronary Syndrome: Better Activities of Daily Living, Longer Life. Clin Cardiol. 2016 Feb; 39(2):83-9. 
27- Cox AM, Mc Kevitt C, Rudd AG, et al. Socioeconomic status and stroke. Lancet Neurol. 2006 Feb; 5(2):181-8.

28- Ahacic K, Trygged S, Kåreholt I. "Income and Education as Predictors of Stroke Mortality after the Survival of a First Stroke," Stroke Research and Treatment, vol. 2012, Article ID 983145, 6 pages, 2012.

29- Bureau of Democracy, Human Rights, and Labor. "2012 Report on International Religious Freedom - Lebanon". 20 May 2013. Available at: <https://www.state.gov/j/drl/rls/irf/2012/nea/208400.htm> (Last accessed on 26 August 2018) 
Table 1. Socio-demographic sample characteristics

\begin{tabular}{|c|c|c|c|c|c|c|c|c|c|c|c|c|}
\hline & \multicolumn{2}{|c|}{ At enrolment } & \multicolumn{2}{|c|}{$\begin{array}{c}\text { Survivors at 1- } \\
\text { month follow up }\end{array}$} & \multicolumn{2}{|c|}{$\begin{array}{c}\text { Deceased at 1- } \\
\text { month }\end{array}$} & \multirow[t]{2}{*}{$\begin{array}{c}\text { P- } \\
\text { value* }\end{array}$} & \multicolumn{2}{|c|}{$\begin{array}{l}\text { Survivors at 1- } \\
\text { year follow up }\end{array}$} & \multicolumn{2}{|c|}{$\begin{array}{c}\text { Deceased at 1- } \\
\text { year }\end{array}$} & \multirow[t]{3}{*}{ P-value**: } \\
\hline & & & & & & & & & & & & \\
\hline & $\begin{array}{c}\mathrm{N} . / \\
\text { mean }\end{array}$ & $\% / \mathrm{SD}$ & $\begin{array}{c}\mathrm{N} . / \\
\text { mean }\end{array}$ & $\% / \mathrm{SD}$ & $\begin{array}{c}\text { N./ } \\
\text { mean }\end{array}$ & $\% / S D$ & & $\begin{array}{c}\text { N./ } \\
\text { mean }\end{array}$ & $\% /$ SD & $\begin{array}{c}\text { N./ } \\
\text { mean }\end{array}$ & $\% / \mathrm{SD}$ & \\
\hline Age mean & 69.2 & 12.6 & 68.0 & 12.3 & 76.6 & 12.2 & 0.001 & 67.4 & 12.0 & 75.8 & 12.0 & $<0.001$ \\
\hline $\begin{array}{l}\text { Gender } \\
\text { Male } \\
\text { Female }\end{array}$ & $\begin{array}{c}109 \\
82\end{array}$ & $\begin{array}{l}57.1 \\
42.9\end{array}$ & $\begin{array}{l}96 \\
68\end{array}$ & $\begin{array}{l}58.5 \\
41.5\end{array}$ & $\begin{array}{l}13 \\
14\end{array}$ & $\begin{array}{l}48.1 \\
51.9\end{array}$ & NS & $\begin{array}{l}83 \\
61\end{array}$ & $\begin{array}{l}57.6 \\
42.4\end{array}$ & $\begin{array}{l}22 \\
20\end{array}$ & $\begin{array}{l}52.4 \\
47.6\end{array}$ & NS \\
\hline $\begin{array}{l}\text { Marital status } \\
\text { Single/ } \\
\text { Divorced/ } \\
\text { Widowed } \\
\text { Married }\end{array}$ & $\begin{array}{c}78 \\
113\end{array}$ & $\begin{array}{l}40.8 \\
59.2\end{array}$ & $\begin{array}{r}62 \\
102\end{array}$ & $\begin{array}{l}37.8 \\
62.2\end{array}$ & $\begin{array}{l}16 \\
11\end{array}$ & $\begin{array}{l}59.3 \\
40.7\end{array}$ & 0.036 & $\begin{array}{l}55 \\
89\end{array}$ & $\begin{array}{l}38.2 \\
61.8\end{array}$ & $\begin{array}{l}21 \\
21\end{array}$ & $\begin{array}{l}50.0 \\
50.0\end{array}$ & NS \\
\hline $\begin{array}{l}\text { Employment } \\
\text { status } \\
\text { Employed } \\
\text { Housewife } \\
\text { Retired } \\
\text { Unemployed }\end{array}$ & $\begin{array}{l}56 \\
78 \\
20 \\
37 \\
\end{array}$ & $\begin{array}{l}29.3 \\
40.8 \\
10.5 \\
19.4 \\
\end{array}$ & $\begin{array}{l}54 \\
64 \\
17 \\
29 \\
\end{array}$ & $\begin{array}{l}32.9 \\
39.0 \\
10.4 \\
17.7 \\
\end{array}$ & $\begin{array}{c}2 \\
14 \\
3 \\
8 \\
\end{array}$ & $\begin{array}{c}7.4 \\
51.9 \\
11.1 \\
29.6 \\
\end{array}$ & 0.050 & $\begin{array}{l}50 \\
57 \\
15 \\
22 \\
\end{array}$ & $\begin{array}{l}34.7 \\
39.6 \\
10.4 \\
15.3 \\
\end{array}$ & $\begin{array}{c}4 \\
20 \\
4 \\
14 \\
\end{array}$ & $\begin{array}{c}9.5 \\
47.6 \\
9.5 \\
33.3 \\
\end{array}$ & 0.004 \\
\hline $\begin{array}{l}\text { Education } \\
\text { Illiterate } \\
\text { Elementary } \\
\text { Secondary } \\
\text { High school } \\
\text { University }\end{array}$ & $\begin{array}{l}36 \\
82 \\
31 \\
26 \\
16\end{array}$ & $\begin{array}{c}18.8 \\
42.9 \\
16.2 \\
13.6 \\
8.4 \\
\end{array}$ & $\begin{array}{l}31 \\
68 \\
28 \\
23 \\
14\end{array}$ & $\begin{array}{l}18.9 \\
41.5 \\
17.1 \\
14.0 \\
8.5 \\
\end{array}$ & $\begin{array}{c}5 \\
14 \\
3 \\
3 \\
2 \\
\end{array}$ & $\begin{array}{l}18.5 \\
51.9 \\
11.1 \\
11.1 \\
7.4\end{array}$ & NS & $\begin{array}{l}29 \\
56 \\
25 \\
22 \\
12\end{array}$ & $\begin{array}{c}20.1 \\
38.9 \\
17.4 \\
15.3 \\
8.3 \\
\end{array}$ & $\begin{array}{c}7 \\
23 \\
5 \\
3 \\
4 \\
\end{array}$ & $\begin{array}{l}16.7 \\
54.8 \\
11.9 \\
7.1 \\
9.5 \\
\end{array}$ & NS \\
\hline $\begin{array}{l}\text { Monthly personal } \\
\text { income (US\$) } \\
<500 \\
{[500-1000]} \\
{[1000-1500]} \\
>1500\end{array}$ & $\begin{array}{c}131 \\
39 \\
10 \\
11\end{array}$ & $\begin{array}{c}68.6 \\
20.47 \\
5.2 \\
5.4\end{array}$ & $\begin{array}{c}107 \\
38 \\
8 \\
11\end{array}$ & $\begin{array}{c}65.2 \\
23.2 \\
4.9 \\
6.7\end{array}$ & $\begin{array}{c}24 \\
1 \\
2 \\
0\end{array}$ & $\begin{array}{c}88.9 \\
3.7 \\
7.4 \\
0.0\end{array}$ & 0.040 & $\begin{array}{c}92 \\
35 \\
7 \\
10\end{array}$ & $\begin{array}{c}63.9 \\
24.3 \\
4.9 \\
6.9\end{array}$ & $\begin{array}{c}37 \\
2 \\
2 \\
1\end{array}$ & $\begin{array}{c}88.1 \\
4.8 \\
4.8 \\
2.4\end{array}$ & 0.017 \\
\hline $\begin{array}{l}\text { Living status } \\
\text { With family } \\
\text { Alone }\end{array}$ & $\begin{array}{c}168 \\
23\end{array}$ & $\begin{array}{l}88.0 \\
12.0\end{array}$ & $\begin{array}{c}147 \\
17\end{array}$ & $\begin{array}{l}89.6 \\
10.4\end{array}$ & $\begin{array}{c}21 \\
6\end{array}$ & $\begin{array}{l}77.8 \\
22.2\end{array}$ & NS & $\begin{array}{c}128 \\
16\end{array}$ & $\begin{array}{l}88.9 \\
11.1\end{array}$ & $\begin{array}{c}35 \\
7\end{array}$ & $\begin{array}{l}83.3 \\
16.7\end{array}$ & NS \\
\hline
\end{tabular}

* comparison patients with 1-month follow up $(\mathrm{n}=164)$ to dead at 1-month $(\mathrm{n}=27)$.

** comparison patients with full follow up $(n=144)$ to dead $(n=42)$. 
Table 2. Clinical sample characteristics

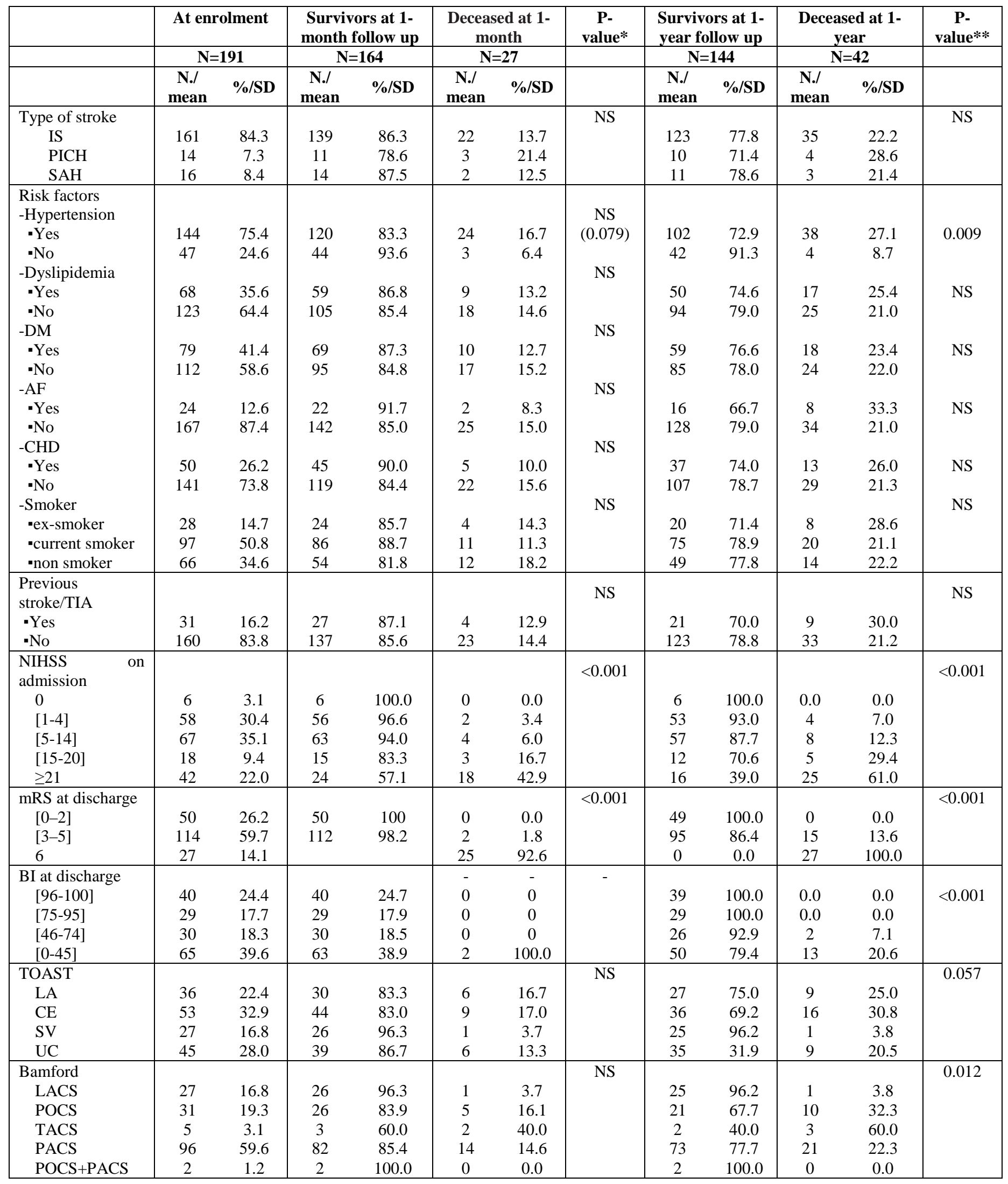




\begin{tabular}{|c|c|c|c|c|c|c|c|c|c|c|c|c|}
\hline $\begin{array}{l}\text { Surgery } \\
\cdot \text { Yes } \\
\text {-No }\end{array}$ & $\begin{array}{c}28 \\
163\end{array}$ & $\begin{array}{l}14.7 \\
85.3\end{array}$ & $\begin{array}{c}23 \\
141\end{array}$ & $\begin{array}{l}82.1 \\
86.5\end{array}$ & $\begin{array}{c}5 \\
22\end{array}$ & $\begin{array}{l}17.9 \\
13.5\end{array}$ & NS & $\begin{array}{c}16 \\
128\end{array}$ & $\begin{array}{l}61.5 \\
80.0\end{array}$ & $\begin{array}{l}10 \\
32\end{array}$ & $\begin{array}{l}38.5 \\
20.0\end{array}$ & 0.037 \\
\hline $\begin{array}{l}\text { Infectious } \\
\text { complication }\end{array}$ & & & & & & & $<0.001$ & & & & & $<0.001$ \\
\hline -Yes & 62 & 32.5 & 40 & 64.5 & 22 & 35.5 & & 29 & 48.3 & 31 & 51.7 & \\
\hline -No & 129 & 67.5 & 124 & 96.1 & 5 & 3.9 & & 115 & 91.3 & 11 & 8.7 & \\
\hline
\end{tabular}

IS=ischemic stroke; TIA=transit ischemic attack; PICH=primary intracerebral hemorrhage; SAH=subarachnoid hemorrhage;

$\mathrm{DM}=$ diabetes mellitus; $\mathrm{AF}=$ atrial fibrillation; $\mathrm{CHD}=$ coronary heart disease; NIHSS= National Institution of Health Stroke Scale; mRS=modified Rankin Scale; BI=Barthel Index; TOAST=Trial of Org 10172 in Acute Stroke Treatment; LA=large-artery atherosclerosis; $\mathrm{CE}=$ cardioembolism; $\mathrm{SV}=$ small-vessel occlusion; $\mathrm{UC}=$ unclassified.

* comparison patients with 1-month follow up $(\mathrm{n}=176)$ to dead at 1-month $(\mathrm{n}=27)$.

** comparison patients with full follow up $(n=156)$ to dead $(n=42)$.

There were 18 patients who were still in the hospital at 1 month, before discharge. Two of them were still alive at 1 month, while still in hospital but were discharged dead from hospital (after 1 month). 


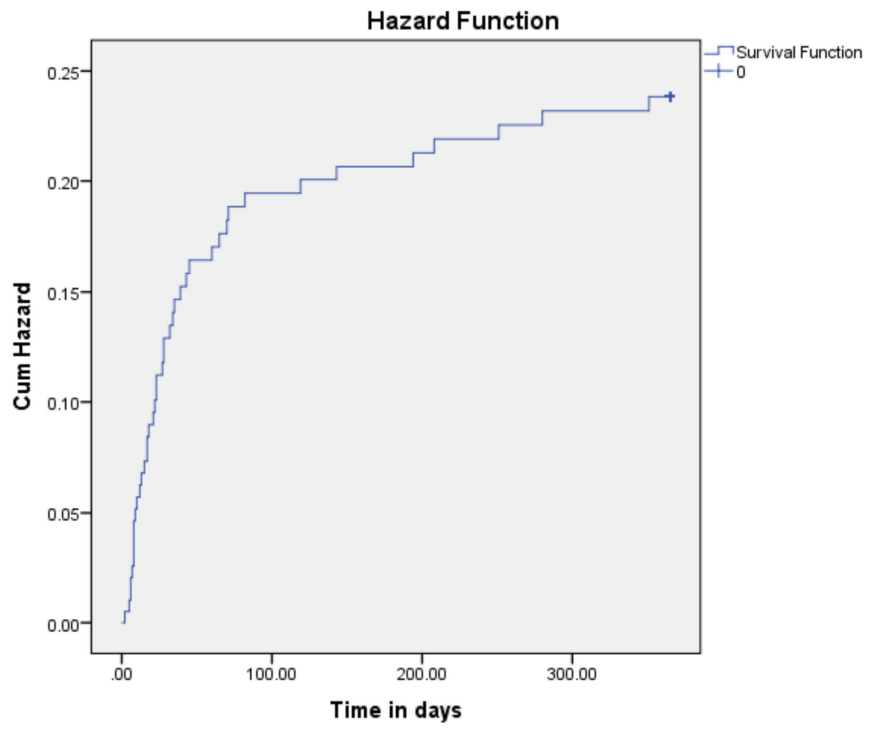

Fig. 1 Kaplan-Meier mortality curve for stroke patients at 1-year follow-up (overall mortality). 
Table 3. Univariate Cox survival regression for determinants of 1-month, 1-year and overall mortality in stroke patients.

\begin{tabular}{|c|c|c|c|c|c|c|c|c|c|c|c|c|}
\hline & \multicolumn{4}{|c|}{ 1-month mortality } & \multicolumn{4}{|c|}{ 1-year mortality ${ }^{*}$} & \multicolumn{4}{|c|}{ Overall mortality } \\
\hline & B & HR & $95 \% \mathrm{CI}$ & $\mathbf{P}$ & B & HR & $95 \% \mathrm{CI}$ & $\mathbf{P}$ & B & HR & $95 \% \mathrm{CI}$ & $\mathbf{P}$ \\
\hline $\begin{array}{l}\text { Age } \\
\leq 64 \text { years }\end{array}$ & & 1 (Ref.) & & & & & & & & 1 (Ref.) & & \\
\hline$>64$ years & 0.9 & 2.4 & [0.9-6.3] & 0.068 & & & & & 0.7 & 2.1 & [1.0-4.4] & 0.045 \\
\hline $\begin{array}{c}\text { Marital status } \\
\text { Single/ } \\
\text { Divorced/ } \\
\text { Widowed } \\
\text { Married } \\
\end{array}$ & -0.8 & $\begin{array}{c}1 \text { (Ref.) } \\
0.4 \\
\end{array}$ & {$[0.2-0.9]$} & 0.038 & & & & & & & & \\
\hline $\begin{array}{l}\text { Monthly personal } \\
\text { income (US\$) }\end{array}$ & -0.7 & 0.5 & {$[0.2-1.1]$} & 0.053 & & & & & -0.6 & 0.5 & {$[0.3-0.9]$} & 0.022 \\
\hline $\begin{array}{l}\text { Living situation } \\
\text { With family } \\
\text { Other } \\
\end{array}$ & 0.8 & $\begin{array}{c}1 \text { (Ref.) } \\
2.1 \\
\end{array}$ & [0.9-5.3] & 0.092 & & & & & & & & \\
\hline Intensive care unit & 2.4 & 11.1 & [2.6-47.1] & $<0.001$ & & & & & 1.4 & 4.1 & [1.9-8.8] & $<0.001$ \\
\hline $\begin{array}{l}\text { Decreased level of } \\
\text { consciousness }\end{array}$ & 1.3 & 3.8 & [1.8-8.2] & $<0.001$ & 1.8 & 5.9 & {$[2.1-16.7]$} & $<0.001$ & 1.5 & 4.5 & [2.4-8.2] & $<0.001$ \\
\hline $\begin{array}{l}\text { Stroke severity on } \\
\text { admission (NIHSS) }\end{array}$ & 0.1 & 1.1 & [1.1-1.2] & $<0.001$ & 0.1 & 1.1 & [1.1-1.2] & $<0.001$ & 0.1 & 1.1 & [1.1-1.2] & $<0.001$ \\
\hline $\begin{array}{l}\text { Infectious } \\
\text { complications }\end{array}$ & 2.4 & 10.7 & {$[4.1-28.4]$} & $<0.001$ & 1.7 & 5.3 & {$[1.9-14.8]$} & $<0.001$ & 2.1 & 7.8 & [3.9-15.7] & $<0.001$ \\
\hline Surgery** & & & & & 1.3 & 3.6 & {$[1.2-10.6]$} & 0.012 & 0.7 & 2.0 & [1.0-4.1] & 0.047 \\
\hline $\begin{array}{l}\text { Barthel Index at } \\
\text { discharge }\end{array}$ & N/A & & & & -1.5 & 0.2 & [0.1-0.7] & 0.003 & N/A & & & \\
\hline $\begin{array}{l}\text { Modified Rankin } \\
\text { Scale at discharge }\end{array}$ & N/A & & & & 2.9 & 18.2 & {$[4.8-68.6]$} & $<0.001$ & N/A & & & \\
\hline Recurrent stroke & & & & & 1.0 & 2.7 & {$[0.9-8.0]$} & 0.057 & & & & \\
\hline Hypertension & 1.0 & 2.7 & {$[0.8-9.1]$} & 0.084 & 1.7 & 5.5 & {$[0.7-42.0]$} & 0.063 & 1.2 & 3.4 & {$[1.2-9.6]$} & 0.012 \\
\hline Atrial Fibrillation & & & & & 1.5 & 4.6 & {$[1.6-12.9]$} & 0.001 & & & & \\
\hline $\begin{array}{l}\text { Employment status } \\
\text { Employed }\end{array}$ & & 1 (Ref.) & & 0.062 & & 1 (Ref.) & & 0.053 & & 1 (Ref.) & & 0.005 \\
\hline Housewife & 1.6 & 5.2 & [1.2-22.9] & 0.029 & 0.9 & 2.6 & {$[0.1-7.1]$} & 0.250 & 1.3 & 3.9 & [1.3-11.4] & 0.013 \\
\hline Retired & 1.5 & 4.5 & {$[0.7-26.8]$} & 0.101 & 0.5 & 1.6 & [0.04-4.13] & 0.689 & 1.1 & 3.1 & {$[0.8-12.3]$} & 0.111 \\
\hline Unemployed & 1.9 & 6.6 & [1.4-30.9] & 0.017 & 1.9 & 6.5 & {$[2.7-51.8]$} & 0.022 & 1.8 & 6.3 & [2.1-19.2] & 0.001 \\
\hline $\begin{array}{l}\text { TOAST } \\
\text { SV }\end{array}$ & & & & & & & & & & 1 (Ref.) & & 0.028 \\
\hline LA & & & & & & & & & 2.0 & 7.5 & {$[1.0-58.9]$} & 0.057 \\
\hline $\mathrm{CE}$ & & & & & & & & & 2.2 & 9.0 & {$[1.2-67.8]$} & 0.033 \\
\hline $\mathrm{UC}$ & & & & & & & & & 1.7 & 5.7 & {$[0.7-44.8]$} & 0.099 \\
\hline $\begin{array}{l}\text { Bamford } \\
\text { LACS }\end{array}$ & & 1 (Ref.) & & 0.088 & & & & & & 1 (Ref.) & & 0.005 \\
\hline POCS & 1.5 & 4.4 & {$[0.5-37.9]$} & 0.175 & & & & & 2.2 & 9.4 & {$[1.2-73.2]$} & 0.033 \\
\hline TACS & 2.7 & 14.8 & [1.3-163.5] & 0.028 & & & & & 3.2 & 25.6 & [2.6-246.2] & 0.005 \\
\hline PACS & 1.4 & 3.9 & {$[0.5-30.0]$} & 0.185 & & & & & 1.8 & 6.2 & {$[0.8-46.1]$} & 0.74 \\
\hline CHD & & & & & 1.1 & 3.2 & {$[1.1-8.7]$} & 0.019 & & & & \\
\hline $\begin{array}{l}\text { Smoker } \\
\text { Non smoker }\end{array}$ & & & & & & 1 (Ref.) & & 0.172 & & & & \\
\hline Ex-smoker & & & & & 1.5 & 2.8 & {$[0.6-12.9]$} & 0.077 & & & & \\
\hline Smoker & & & & & 1.0 & 4.6 & {$[0.8-25.3]$} & 0.189 & & & & \\
\hline
\end{tabular}

*Among 1-month survivors only.

** Surgery types were: coiling, craniotomy, shunt, carotid endarterectomy, gastrostomy and tracheostomy.

The 2 patients who had POCS+PACS were grouped with PACS group for statistical analysis purpose. 
Table 4. Multivariate Cox survival regression for determinants of 1-month, 1-year and overall mortality in stroke patients

\begin{tabular}{|c|c|c|c|c|c|c|c|c|c|c|c|c|}
\hline & \multicolumn{4}{|c|}{ 1-month mortality } & \multicolumn{4}{|c|}{ 1-year mortality ${ }^{*}$} & \multicolumn{4}{|c|}{ Overall mortality } \\
\hline & B & HR & $95 \% \mathrm{CI}$ & $\mathbf{P}$ & B & HR & $95 \% \mathrm{CI}$ & $\mathbf{P}$ & B & HR & $95 \% \mathrm{CI}$ & $\mathbf{P}$ \\
\hline $\begin{array}{l}\text { Stroke severity } \\
\text { on admission } \\
(\mathrm{NIHSS})\end{array}$ & 0.1 & 1.1 & [1.02-1.12] & 0.004 & & & & & 0.1 & 1.1 & [1.05-1.12] & $<0.001$ \\
\hline $\begin{array}{l}\text { Infectious } \\
\text { complications }\end{array}$ & 1.4 & 4.2 & {$[1.3-12.8]$} & 0.013 & & & & & 1.1 & 3.0 & [1.3-6.8] & 0.007 \\
\hline $\begin{array}{l}\text { Barthel Index at } \\
\text { discharge }\end{array}$ & & & & & -2.0 & 0.14 & [0.04-0.50] & 0.003 & & & & \\
\hline Recurrent stroke & & & & & 1.5 & 4.7 & {$[1.2-17.6]$} & 0.024 & & & & \\
\hline Hypertension & & & & & & & & & 1.1 & 2.9 & {$[1.0-8.3]$} & 0.050 \\
\hline $\begin{array}{l}\text { Atrial } \\
\text { Fibrillation }\end{array}$ & & & & & 1.5 & 4.6 & [1.1-19.2] & 0.035 & & & & \\
\hline $\begin{array}{l}\text { Employment } \\
\text { status }\end{array}$ & & & & & & & & 0.003 & & & & 0.007 \\
\hline Employed & & & & & 1 (Ref.) & & & & 1 (Ref.) & & & \\
\hline Housewife & & & & & 0.2 & 1.3 & [0.1-11.6] & 0.828 & 0.697 & 2.0 & {$[0.7-5.9]$} & 0.207 \\
\hline Retired & & & & & -0.6 & 0.5 & [0.03-10.9] & 0.696 & 0.550 & 1.7 & {$[0.4-7.0]$} & 0.438 \\
\hline Unemployed & & & & & 2.7 & 15.1 & [1.7-131.3] & 0.014 & 1.684 & 5.4 & {$[1.7-16.7]$} & 0.003 \\
\hline
\end{tabular}

*Among 1-month survivors only.

\section{Supplementary file}

Table 5. Multivariate Cox survival regression for determinants of overall mortality in ischemic stroke patients

\begin{tabular}{|l|cccc|}
\hline & \multicolumn{4}{|c|}{ Overall mortality } \\
\hline & B & HR & 95\% CI & P \\
\hline $\begin{array}{l}\text { Stroke severity on } \\
\text { admission (NIHSS) }\end{array}$ & 0.1 & 1.1 & {$[1.03-1.12]$} & 0.001 \\
\hline $\begin{array}{l}\text { Infectious } \\
\text { complications }\end{array}$ & 1.6 & 5.0 & {$[1.9-12.7]$} & 0.001 \\
\hline Barthel Index at \\
discharge
\end{tabular}

